\title{
LA REPRESENTACIÓN DE LA MUJER EN MORIR SOLA (1910) DE MARÍA DEL PILAR SINUÉS, LA ROCA DEL AMOR (1924) DE DOLORES DE GORTÁZAR SERANTES Y QUIERO VIVIR MI VIDA (1931) DE CARMEN DE BURGOS
}

\author{
Elisabeth Delrue ${ }^{1}$ \\ Universidad Picardie Jules Verne
}

Fecha de recepción: 13/09/2021

Fecha de aceptación: 14/11/2021

\begin{abstract}
Resumen
Se pretende ilustrar de qué manera la literatura participa de ese discurso social, definido por Marc Angenot, como sistema, que rige y organiza cuanto se dice y se escribe en un estado de sociedad, al compartir el imaginario literario y social, la misma dinámica de construcción de nuevos modelos de comportamiento. Para ello, el análisis de la representación de la mujer, en el sentido de Louis Marin, se basará en el proceso de comunicación literario iniciado por sus respectivas autoras desde planteamientos ideológicos propios, el cual implicando un emisor y un receptor presupone un mensaje destinado a ejercer una acción.
\end{abstract}

Palabras clave: discurso social, imaginario literario, modelo de comportamiento, representación, mujer, proceso de comunicación literario.

\begin{abstract}
The aim is to illustrate how literature participates in the social discourse defined by Marc Angenot as a system that governs and organizes what is said and written in a state of society by sharing the same dynamics of construction of new models of behavior in the literary and social imaginary. To this end, the analysis of the representation of women, in the sense of Louis Marin, will be based on the literary communication process initiated by their respective authors from their own ideological approaches, which imply a sender and a receiver that presupposes a message aimed to exercise an action.
\end{abstract}

Keywords: social discourse, literary imaginary, role model, representation, woman, literary communication process.

\footnotetext{
${ }^{1}$ Profesora Titular de Universidad Picardie Jules Verne, Departamento de español UFR de Langues et Cultures Etrangères Amiens; marie-elisabeth.delrue@u-picardie.fr / elisabeth.delrue@wanadoo.fr

Raudem, Revista de Estudios de las Mujeres. Vol. 9, 2021. ISSN: 2340-9630

https://doi.org/10.25115/raudem.v9i1.6424

(C) Publicado bajo licencia Creative Commons BY-NC-ND 4.0
} 
María del Pilar Sinués, Dolores de Gortázar Serantes y Carmen de Burgos ocupaban el espacio público de las letras como periodistas, escritoras, traductoras y ensayistas dando voz a planteamientos ideológicos propios. La primera, católica practicante, abogaba por ideas conservadoras asentadas en el concepto del ángel del hogar como marco definitorio del modelo decimonónico de mujer ideal. La segunda, colaboradora de El Cruzado español y presidenta de Margaritas madrileñas, buscaba contrarrestar el feminismo de los enemigos del catolicismo alentando el trabajo de las mujeres en la acción jaimista. La tercera ejerció de maestra, fue miembro de la Residencia de Señoritas, Lyceum Club, la Asociación de Mujeres Universitarias, y defendía ideas progresistas y feministas.

Escogiendo una novela de cada una de ellas, publicadas en décadas distintas del siglo XX, y, basándonos en el proceso de comunicación literario iniciado por sus respectivas autoras ${ }^{2}$, se pretende ilustrar de qué manera la literatura participa de ese discurso social, definido por Marc Angenot ${ }^{3}$, al tener el imaginario literario, la misma dinámica de construcción de nuevos modelos de comportamiento que el imaginario social.

Teniendo presente este objetivo, analizaremos la representación de la mujer en las tres novelas escogidas, utilizando el concepto en el sentido de Louis Marin, para quien, representar significa presentarse representando algo y representar algo para ciertos fines (Marin 1994: 255). Ello implica estudiar dos aspectos entremezclados en los libros analizados. El primero radica en la emergencia de la construcción ideológica que vertebra la representación de la mujer en la identidad discursiva del locutor, tal como se revela y aflora en el discurso ${ }^{4}$, inscrita a tres niveles, semántico, sintáxico y pragmático, captada en su enunciación ${ }^{5}$, patente en el juego de pronombres y tiempos verbales (Benvéniste 1966: 228), adjetivos evaluativos y verbos subjetivos (Kerbrat-Orecchioni 1999: 100103). El segundo estriba en los posibles roles rediseñados que asigna cada autora a las mujeres españolas, programados gracias a las opciones lingüísticas elegidas, condicionadas por la relación entre emisor y receptor. Éstas van destinadas a programar la adhesión, en la figura del lector anónimo sin identidad verdadera, apostrofado por el narrador a lo largo del relato y/o lector desdibujado, no descrito ni nombrado, pero sí implícitamente presente, a través del saber que el narrador supone existir en la

\footnotetext{
${ }^{2}$ Éste implica un emisor, así como un receptor y presupone un mensaje destinado a ejercer una acción sobre el mismo.

${ }^{3}$ Sistema que rige y organiza cuanto se dice y se escribe en un estado de sociedad (Angenot 1989: 13-14).

${ }^{4}$ Inclusión de un texto en sus condiciones de producción y recepción (Adam 1999: 39).

5 “acto individual de la locución en el que se muestra el hablante [...]" (Marchese y Forradellas 1991: 127).
} 
personalidad culta de su destinatario (Jouve 1993: 28). Este aflorará en el abanico de referencias culturales presupuestamente compartidas, salpicadas en el relato, relacionadas con los valores ideológicos históricamente determinados de los miembros de la interacción, el autor y el lector, siendo ambos sujetos culturales ${ }^{6}$, anclados en el imaginario de una época ${ }^{7}$.

Este previo acercamiento a los dos aspectos mencionados nos llevará a confirmar el enfoque ideológico destacado en la dimensión extra o prediscursiva del enunciador (Adam 1999: 114), es decir, el conocimiento que se tiene de las escritoras antes de la elaboración de sus respectivas novelas. Éste se percibirá en sus escritos anteriores, o, en el caso de Dolores de Gortázar Serantes, en El Cruzado español, periódico que recoge sus artículos o ensalza su labor de periodista y presidenta de las Margaritas madrileñas, en favor de la Comunión tradicionalista, apuntando su orientación ideológica ${ }^{8}$.

En suma, a nuestro juicio, cada autora pretende incitar al lector a reorientar su identidad personal, aplicando en su propia vida los valores y normas que le proponen las protagonistas esbozadas como modelo, gracias a la refiguración de la mímesis ${ }^{9}$ y a su identificación a ellas favorecida por su implicación personal y afectiva (Iser 1994: 154157).

La demostración del planteamiento que venimos detallando constará de tres apartados: una estructura antagónica como manera de suscitar la repulsión o la simpatía del lector; la identificación del lector a las figuras ansiadas como modelo; verdades consagradas como plataforma de difusión del ideario de cada autora.

\footnotetext{
6 "miembro de una comunidad cuyos modelos socio-culturales ha interiorizado, a lo largo de su vida, desde la infancia" (Cros 2005: 16).

${ }^{7}$ Las representaciones sociales vigentes, los esquemas preconcebidos e interiorizados.

8 "Semanario defensor de la Comunión católico-monárquica" una de las denominaciones adoptadas por el movimiento carlista.

${ }^{9}$ En Temps et récit, el filósofo francés desdobla en tres dimensiones la noción aristotélica de mímesis. Asimila la configuración narrativa mímesis II (Ricoeur 1984) a la mediación en tanto temporalidad narrada entre una prefiguración mímesis I ligada a las acciones de la vida cotidiana que corresponde al caudal cultural en el que está inserto el autor (Ricoeur 1983) y una refiguración mímesis III a través de la lectura que corresponde a la relación obra-lector a partir de la cual, éste puede llegar a cambiar su obrar en la vida real (Ricoeur 1985).
} 


\section{UNA ESTRUCTURA ANTAGÓNICA COMO MANERA DE SUSCITAR LA REPULSIÓN O LA SIMPATÍA DEL PÚBLICO LECTOR}

Para encauzar adecuadamente la acción del lector de su obra en la vida real, cada autora recurre a dos estrategias narrativas entreveradas, una estructura antagónica ${ }^{10}$ y un haz de experiencias vitales paralelas.

La estructura antagónica es la lógica consecuencia de la textualización del mundo representado facilitada por el sujeto de la enunciación, abiertamente maníquea. Se oponen claramente, en los libros analizados, las figuras que encarnan la modernidad a las que representan la tradición católica. Pero, $\operatorname{los}$ retratos $^{11}$ incitan mecánicamente al lector a adoptar el posicionamiento ideológico de quienes están presentados positivamente y a rechazar el ideario de los que se oponen a él, sistemáticamente esbozados negativamente.

Con el haz de experiencias vitales paralelas, esta vez, cada autora invita al lector a adoptar el comportamiento de los buenos, incitándole a identificarse virtualmente con ellos, adaptando su actitud a la moral que vio triunfar y a seguir la buena vía encarnada por el espacio eufórico al cual les conduce su evolución. De esa manera adquiere los beneficios de una experiencia que todavía no ha vivido pero que puede transferir en su propia existencia. Ante todo, se le induce a adoptar el comportamiento que valora el sujeto de la enunciación en conformidad con la ideología de la escritora de carne y hueso de la que dimana. En este aspecto, los respectivos títulos de cada libro, en tanto que manifestación explícita de la voz de la autora, quien los asume pragmáticamente, participan del control discursivo conllevando su clave interpretativa. Gracias a las entidades lingüísticas que los componen, los tres contribuyen a su designación temática cumpliendo una función connotativa que remite al efecto producido (Genette [1987] 2001: 51-82) : en la novela de María del Pilar Sinués, un desenlace aterrador formulado en infinitivo, a modo de castigo divino, en la de Dolores de Gortázar Serantes una referencia topográfica que suscita curiosidad, en la de Carmen de Burgos perspectivas esperanzadoras expresadas en la primera persona del singular de quien decide tomar las riendas de su vida.

\footnotetext{
${ }^{10}$ Conflicto que puede tomar la forma de cualquier confrontación, poniendo en juego valores distintos del avance o el interés propio entre dos fuerzas, identificándose la del héroe como la del Bien y la otra como la del Mal. (Suleiman 1983: 126-127).

${ }^{11}$ Cifra de rasgos morales, psicológicos y físicos que se nos proporcionan de los personajes que integran ambos campos.
} 


\title{
1.1. Morir sola (1910) de María del Pilar Sinués
}

Hasta bien entrado el siglo XX, la postura conservadora de la Iglesia acude a la rígida división de esferas que mantiene la reclusión natural de la mujer en el ámbito doméstico. Le atribuye una sublime misión de madre y de ángel del hogar, entre las cuatro paredes de su casa, donde debe atesorar obediencia y sometimiento, para no poner en peligro la institución de la familia tradicional (Nash 1983: 44-45). El sujeto de la enunciación de la novela aquí analizada opone con toda nitidez dos tipos de mujeres. Por un lado, valora positivamente en la evocación que de ellas facilita al lector a las que se ajustan perfectamente a los requisitos asociados a la figura del ángel del hogar. Por otro lado, califica negativamente a las que los desbaratan rotundamente. En la primera categoría sobresale Cecilia Bustamante como apunta la siguiente cita:

\begin{abstract}
No creas, lector mío que yo he tratado de pintar en Cecilia Bustamante un tipo sublime y del todo distinto de la generalidad de las mujeres; si hay en ella alguna sublimidad nacerá de su misma sencillez y virtud; este retrato está sacado del natural y tiene muchas semejantes y tendrá cada día mayor número. Era una criatura educada en sólidos principios de virtud y de piedad cristiana que se había dedicado al trabajo asiduo y mortificante de una servidumbre más dura bajo sus formas cultas y distinguidas. (Sinués 1910: 238-239)
\end{abstract}

En estas líneas, de entrada, el plano de la subjetividad con el uso de la primera persona, en los pronombres y posesivos, de acuerdo a la actitud de enunciación elegida, la del discurso, organizada en torno a la categoría de persona, apela a la participación intelectual activa del lector al que se trata de convencer. Después, deja paso al de la tercera persona, el cual excluyendo marcas deícticas evita que se considere lo expresado como una opinión subjetiva del locutor. Por tanto, pone en los destinatarios la prueba de que lo que viene diciendo es la verdad ${ }^{12}$ : "si hay en ella alguna sublimidad nacerá de su misma sencillez y virtud", "educada en sólidos principios de virtud y de piedad cristiana". Al poderse dividir los adjetivos subjetivos entre $\operatorname{los} \operatorname{afectivos}^{13}$ y los evaluativos axiológicos ${ }^{14}$

\footnotetext{
${ }^{12}$ La división que establece el lingüista francés Emile Benvéniste entre los dos planos de enunciación (historia y discurso) se fundamenta también en la utilización de esos tiempos verbales destinada a evidenciar el borramiento del enunciador que parece "ausentarse" haciendo como si la historia se contara por sí sola (Benvéniste 1966: 237-250).

${ }^{13}$ Enuncian una propiedad del referente introduciendo una reacción emocional del sujeto hablante hacia él.

${ }^{14}$ Transmiten un juicio de valor positivo o negativo sobre el sustantivo al que acompañan.
} 
(Kerbrat-Orecchioni 1999: 95-97; 100-103), aquí, la adjetivación hiperbólica "sublime” declinado en su forma de sustantivo "sublimidad", "sólidos", "cultas y distinguidas" evidencia la valoración favorable de quien la utiliza. Más adelante, también son atribuibles al sujeto de la enunciación, la evaluación positiva de Cecilia Bustamante y el enjuiciamiento negativo de quienes fomentan su malestar. Los evaluativos axiológicos ensalzan las prendas de la primera "modesta", "tan amante del orden", "tan laboriosa", "tan sencilla", "tan noblemente dedicada" para suscitar la simpatía del lector hacia ella. En cambio, los términos "Aquel desorden", “donde abundaba todo lo superfluo", "se carecía de todo lo necesario", "formaba una atmósfera que ahogaba" generan la repulsión del que los lee, hacia las formas de vida de quienes las instauran (Sinués 1910: 240).

Entre las que desbaratan el modelo definitorio del ángel del hogar, destacan Alicia y su madre Sofía. En las próximas palabras relativas a la hija, la pregunta retórica “¿quién puede describir los mil accidentes de una vida semejante, ni cómo revolver ni agitar el légamo, que está tan cerca del cieno que participa de sus miasmas?", le permite, al enunciador, afirmar algo que considera verdadero, haciendo que el destinatario descubra la verdad, en la respuesta posible, imponiéndole un modo peculiar de ver las cosas. Para ello, recurre, a la enumeración de metonimias y sinécdoques, y a la adjetivación hiperbólica con fines irónicos: "La estafa simulada, la tercería elegante, el vicio bajo su ropaje más dorado y más culto, una sociedad brillante y hasta cierto punto escogida". También se vale de la contraposición maníquea de redes paradigmáticas entre los requisitos valorados del ángel del hogar, el cristiano amor a lo "bello, bueno, noble y sincero", "esposo, hijos" y los atributos opuestos a ellos, "afición al lujo", "monstruoso egoísmo", "antipatía que le causaba cuanto era bello, bueno, noble y sincero". En otras palabras, contrapone los paradigmas ateísmo vs catolicismo, egoísmo vs dedicación a su familia, opresión vs felicidad, odio y horror por las cuatro paredes de su casa vs belleza, bondad, nobleza, sinceridad:

No hay para qué describir los detalles de la nebulosa existencia de Clarisa Robson en Madrid, ni acaso sería posible hacerlo: ¿quién puede describir los mil accidentes de una vida semejante, ni cómo revolver ni agitar el légamo, que está tan cerca del cieno que participa de sus miasmas? La estafa simulada, la tercería elegante, el vicio bajo su ropaje más dorado y más culto, una sociedad brillante y hasta cierto punto escogida: tales eran los elementos que componían el centro adonde Alicia, ya pervertida por el ateísmo y la infamia moral de la irlandesa fué á parar, y sintió 
desarrollarse y crecer su afición al lujo, su monstruoso egoísmo y la antipatía que le causaba cuanto era bello, bueno, noble y sincero; algunas veces sentía en su alma como un hastío mortal, como un ansia ardiente de sacudir todo lo que la oprimía: esposo, hijos, la vieja Catalina, la casa, entre cuyas paredes se ahogaba; todo esto era para aquella mujer objeto de odio y de horror. (Sinués 1910: 147)

En las líneas que se referían anteriormente a Sofía, el uso del presente gnómico y de la no persona en "infeliz muestra de la mujer de nuestros días que desdeña todo lo bueno y grande y se consagra en cuerpo y alma al culto de lo frívolo y de lo exterior" colocaba a los destinatarios en una posición de objetividad que les inducía a admitir la validez de evaluativos axiológicos, sinécdoques y metonimias que componían lo enunciado (Sinués 1910: 25).

La programación llevada a cabo, en toda la novela, incita, pues, al lector, a descartar en su existencia real, las formas de vida de Sofía y Alicia porque abocan a la extrema miseria y a la soledad: "Aquella mujer que había hecho del lujo su pasión y de la elegancia su culto volvía a la vida en la camilla de un hospital" (Sinués 1910: 457). En cambio, se le empuja a adoptar los hábitos de Cecilia Bustamante, a apropiarse de los valores que defiende, acordes con los del sujeto de la enunciación pues conducen a mejores resultados. Éstos se valoran, en la cita siguiente, con la contraposición antitética entre el entorno opresivo y nefasto propiciado por una actitud desligada de la religión y el alivio facilitado por la observación de los preceptos divinos: "Después de dos meses de opresión y de fatiga moral allí en medio de la Naturaleza era menos desdichada porque veía más cerca a Dios" (Sinués 1910: 252).

\subsection{La roca del amor (1924) de Dolores de Gortázar Serantes}

Desde el principio, el carlismo, con la oposición de Carlos María Isidro, hermano menor de Fernando VII, a la subida de su hija Isabel al trono, provocando así su primera guerra (1833-1840), no es sólo un conflicto dinástico sino la resistencia del Antiguo Régimen contra el liberalismo superpuesta al antagonismo entre tradición y modernidad.

En esta novela, el sujeto de la enunciación, en conformidad con el ideario carlista de la escritora de la que dimana, opone, por tanto, dos clases sociales, la aristocracia y el pueblo. Por un lado, valora las prendas físicas de las mujeres del primer estamento con términos encomiásticos, por el otro, evoca la fisonomía de quienes integran el segundo con palabras punzantes y mordaces como demuestran las siguientes citas: "La madre de 
Blanca fue una respetable señora de abolengo, oriunda de León pero que poseía ricas fincas en la región levantina" (Gortázar Serantes 1924: 17). Aquí, la mera mención de la tierra valenciana, calificada de divina por guardar la Madre de los Desamparados en la dedicatoria al insigne Doctor D. Joaquín Ferris (Gortázar Serantes 1924: 5) apunta una valoración positiva en la adecuación metonímica entre el espacio y quien lo ocupa, resaltada por la previa adjetivación elogiosa "respetable" caracterizadora de sus atributos morales. A Lucila, madre de Rosa, condesa de Morgobejo, se la singulariza, ensalzando su apariencia física "aristocrática en los modales, sencilla en el vestir" y patentizando los defectos hiperbolizados de su personalidad "Carácter altivo, inflexible, de acero" (Gortázar Serantes 1924: 68-69), indicio de las críticas de que van a ser objeto. De hecho, lo que se pretende en la novela es reorientar las competencias morales de las mujeres de la nobleza hacia el verdadero mensaje de Cristo (misericordia y perdón). En cambio, a doña Mónica se le califica negativamente de "mujer apergamada de mediana estatura, de mirada beatífica con todas las trazas de una vieja del aquelarre envuelta en negro manto" (Gortázar Serantes 1924: 49), provocando la asimilación metafórica con una bruja repulsión y rechazo en el lector

Para cumplir con la reorientación perseguida, se utilizan varias estrategias narrativas. Primero, la textualización del encuentro de la propia escritora con Edmundo, oficial de marina, marido de Rosina (Gortázar Serantes 1924: 10), finalmente, hermano suyo, y Don Pablo, el sacerdote, primo de Lucila, padrino de Rosa, ambos de estamento nobiliario, contribuye a hacerle olvidar al lector la dimensión ficticia de la obra que está leyendo. También acrecienta su ansiada implicación en el relato, atribuyéndoles a los dos, el papel de sucesivos narradores intradiegéticos-homodiegéticos ${ }^{15}$ porque cuadra perfectamente su respectivo cargo con el ethos aristotélico al presuponer cualidades morales, y, por tanto, merecimiento de confianza (Aristóteles 1999: 1356). Segundo, se le propone al lector las experiencias vitales paralelas de dos niñas nobles, la de Rosa y la de Rosina, quienes simpatizaron por sus almas (Gortázar Serantes 1924: 195). El descarrío de la primera fue fruto de la fracasada educación que su madre, la condesa de Morgobejo, les impuso a ella y a su hermano Enrique. Enamorada del pintor Berlanga, para el que posó como modelo de la Purísma, quien abandonó a la mujer y a sus tres hijos para huir con ella, Rosa dio a luz a un Julito, fruto del adulterio. Luego, acabó casándose con el padre biológico, enviudó y contrajo segundas nupcias con el propio Edmundo. En

${ }^{15}$ Pertenecen al mundo que se narra en calidad de personajes o testigos de la historia que se cuenta (Genette 1980: 302-303). 
cambio, la exitosa educación facilitada en el colegio de las Madres de Loreto en Valencia, a Rosina, presunta hija de pescadores, y, en realidad, hija del marqués de Lille y de Elena Julia como se nos revela al final del libro (Gortázar Serantes 1924: 126-128), le permitió seducir a Edmundo quien aspiró a casarse con ella.

Los retratos, cifra de rasgos morales, psicológicos y físicos que se nos proporcionan de los personajes incitan, mecánicamente, al lector a adoptar el comportamiento y la forma de ser de quienes están presentados positivamente y a rechazar el ideario de los que se oponen a ellos, sistemáticamente esbozados de forma negativa. A lo largo de la novela, el blanco de la crítica es la condesa de Morgobejo cuyas ocupaciones resume el sujeto de la enunciación, evidenciando, con hipérboles, la inutilidad de las tareas emprendidas: "La condesa era miembro de infinitas cofradías, razón por la que no podía cumplir con ninguna y se consagraba en cuerpo y alma a rezos y meditaciones, visitando las iglesias durante el día" (Gortázar Serantes 1924: 69). Y para encauzar las prácticas religiosas apropiadas entre los lectores, cede la palabra a Don Pablo, el sacerdote, quien apunta los preceptos básicos asociados a una buena católica tanto a las mujeres del pueblo (Gortázar Serantes 1924: 49-51) como a su prima Lucila, bajo la forma de réplicas alternadas, permitiendo la participación directa del lector a los argumentos aducidos como en las líneas siguientes:

Educa, en el temor de Dios, a los niños, no les alejes de tu lado, son tu corona, el único amor que tienes, no violentes su vocación. Forma en Rosa, una mujer discreta, agradable de virtud, sana de alma y fuerte de cuerpo, que sea un ángel de la familia. Cuando tenga suficiente discernimiento, inclínala para que sepa elegir digno compañero y tú gozarás viéndole feliz. Si así no lo haces y si obligas a Enrique a ingresar en el Seminario, pecarás mortalmente y de nada te servirán tus beatas y tus rezos. Y en vez de salvar a tus hijos, los perderás del todo. (Gortázar Serantes 1924: 76-77)

En ellas, las oraciones, en imperativo, a modo de recomendaciones y amonestaciones, ponen énfasis en los pilares de la educación católica, articulados en torno al papel de madre y abocados a preparar a las niñas a su misión de ángel del hogar, valorando las prendas necesarias para cumplirla "discreta, agradable de virtud, sana de alma y fuerte de cuerpo, que sea un ángel de la familia”. También, destacamos el recurso de la sinécdoque "tu corona el único amor que tienes" que pondera la valía de los hijos para su madre. La 
amenaza blandida de pecado mortal ${ }^{16}$ así como de perdición ${ }^{17}$ apunta conjuntamente y con la certeza del tiempo futuro las falsas vocaciones por forzadas, el tiempo perdido en las plegarias y el desenlace previsto en caso de desobediencia a los preceptos enunciados.

El diálogo cumple el papel de recordar la misericordia y el perdón como fundamentos del cristianismo en palabras del sacerdote y descalificar, con varios recursos, la terquedad altiva de quien se resiste a aplicarlos:

Y tu madre no te perdonará ni en vida ni en muerte-replicó la condesa con firme acento.

Lucila, Jesús perdonó a los que le cruxificaron y era un Dios. Y tú pides en el padrenuestro que perdone tus deudas como tú perdonaste a tus deudores. ¿Comprendes lo que esto significa? Si no eres misericordiosa con tu hija, el Señor tampoco te perdonará.

¡Soy inexorable! Dios me juzgará por mis virtudes. ¡No temo, pues, su juicio! ¡Ha muerto para su madre! Y decidida, altiva, inconmovible, salió del salón sin atender a mis ruegos ni a las súplicas de su hija que se deshacía en lágrimas. (Gortázar Serantes 1924: 83-84)

El primero es la negativa de intercambio obvia en la tonalidad perentoria y terminante de las respuestas de Lucila señalada por los signos de exclamación, el presente de indicativo que traduce intemporalidad o el futuro que expresa certeza "_;Soy inexorable! Dios me juzgará por mis virtudes. ¡No temo, pues, su juicio! ¡Ha muerto para su madre!”. El segundo es la adjetivación sinonímica que señala, de manera redundante, dicha obstinación desvariada "firme", "decidida", "altiva", "inconmovible". El tercero es la búsqueda de empatía en el lector apelando al pathos que suscita sus afectos y provoca su compasión e indignación con la mención de "las súplicas de su hija que se deshacía en lágrimas".

En otros momentos, Don Pablo le confiere obviamente a Rosa el estatuto de víctima y no de pecadora (Gortázar Serantes 1924: 44) e incluso, más adelante, achaca a su madre su extravío y al designio divino su redención posterior guiada por él (Gortázar Serantes 1924: 88). Coincide con el sujeto de la enunciación quien implicaba directamente a su madre apuntalándola como única responsable del desliz de su hija, en líneas anteriores.

\footnotetext{
16 "Si así no lo haces y si obligas a Enrique a ingresar en el Seminario pecarás mortalmente y de nada te servirán tus beatas y tus rezos"

17 "Y en vez de salvar a tus hijos los perderás del todo"
} 
En ellas recurría, primero, a dos tipos de metáforas, la pajarera "Una palomita entre las garras del gavilán" y la bélica "La plaza estaba desde el primer asedio rendida y le fue facilísimo al pintor el tomarla", para dramatizar la evocación de su enamoramiento repentino, reforzándola con la adjetivación hiperbólica “violenta”, “facilísimo”. Invocaba luego, su debilidad de creer en la piedad fingida del seductor "cautivada por la hipocresía de Berlanga":

...por no haber tratado más hombres que al confesor y los graves profesores que dirigían sus estudios quedó en dominio de la violenta pasión del pintor Berlanga quien la tomó como modelo. (...) Una palomita entre las garras del gavilán. La plaza estaba desde el primer asedio rendida y le fue facilísimo al pintor el tomarla. Se ahogaba Rosa al lado de su madre. Y ésta cautivada por la hipocresía de Berlanga, dejaba a su hija en plena libertad, porque era un escudo firme la piedad fingida del seductor. (Gortázar Serantes 1924: 86)

\subsection{Quiero vivir mi vida (1931) de Carmen de Burgos}

En esta novela, el sujeto de la enunciación opone con toda nitidez a dos tipos de mujeres, esbozándolas negativa o positivamente con vistas a incitar mecánicamente al lector a adoptar el posicionamiento ideológico que defiende. El blanco de su sátira se constituye fundamentalmente en las que se aferran a la tradición católica y sus recomendaciones seculares. En cambio, suscita la simpatía del lector hacia las que pretenden combatirlas librándose de ellas en nombre de la modernidad. Entre las primeras, se cuentan la madre de Isabel, doña Milagros y su propia hermana Rosita; entre las segundas, destacan Isabel y Lina su mejor amiga.

A Doña Milagros le asocia el conservadurismo acérrimo. Por un lado, de manera implícita, facilita la referencia indirecta a los requisitos del ángel del hogar valorados, por inferencia, desde el rechazo hiperbólico hacia la coquetería: "Experimentaba gran antipatía por las que se pintaban las uñas, refinamiento que creía incompatible con las tareas del hogar". Por otro lado, explícitamente, menciona su apego a todas sus manifestaciones: "Se entendía en todo eso muy bien con Antonio, tan comilón como ella, apegado a todo conservadurismo" (Burgos 1931: 35). También, a menudo, facilita su forma de pensar, en estilo directo, como respuesta a quienes cuestionan la tradición católica para permitir la participación directa del lector a su argumentación. Como botón 
de muestra, las siguientes líneas apuntan el enfrentamiento ideológico entre Isabel y doña Milagros, induciendo a quien las lee a aceptar por sensatas las alegaciones de la primera presentada como reflexiva y a descartar las de su madre por enunciadas, en presente gnómico, como ley general, impuesta por el dogma evangélico a las hembras cristianas que, por tanto, deben admitir:

Rosita quiere ser cadañera, como mi tía Lola, que tuvo veintiuno.

— Le costaría trabajo conocerlos-dijo budona Isabel.

— No vivieron todos. Se le murieron diez y ocho.

— ¿Para qué tener tantos entonces?

Fué doña Milagros la que respondió:

- Para hacer la voluntad del Altísimo. Van al cielo a rogar por nosotros. (Burgos 1931: 36)

En otro momento, el sujeto de la enunciación alterna narración, estilo directo e indirecto para dar nítida cuenta de la dicotomía ideológica entre modernidad y tradicionalismo, encarnación del enfrentamiento entre las dos Españas. Entonces, aventaja la directa plasmación de los argumentos aducidos por doña Manuela "republicana y librepensadora" a expensas de los expuestos por doña Milagros, "ferviente católica" acerca del catolicismo y de la condición de la mujer que define. Persiguiendo esta pretensión, reproduce íntegramente la evaluación altamente negativa del contenido de la Biblia en palabras de Doña Manuela agudizándola con expresiones hiperbólicas "inmoral”, "atrocidades mayores” y su lastimada percepción de la condición femenina que conlleva. En cambio, se limita a parafrasear en estilo indirecto las palabras de su interlocutora, dándoles menos peso y vigencia para quienes las leen:

Doña Manuela se reía de las interpretaciones de su amiga.

— La Biblia—decía — es un libro inmoral. En ninguna parte he leído atrocidades mayores.

Doña Milagros la llamaba al orden. Ella era ferviente católica y no le gustaba que doña Manuela hablara así y escandalizase a las demás señoras con sus juicios radicales de republicana y librepensadora.

— Eso está feo-le decía. Hasta a los hombres más radicales no les gusta que las mujeres sean así. 
— ¿Qué desgracia ser mujer! — exclamaba convencida doña Manuela. (Burgos 1931: 69)

También, al atribuir la disparidad de carácter y comportamiento de ambas hermanas a la respectiva influencia educativa ejercida por la madre en Rosa y por el padre en Isabel, se contraponen los resultados de cada tipo de educación. Valora el que erige la hembra al nivel del varón en los hábitos inculcados para combatir la desigualdad de género y descarta el que facilita doña Milagros destinado a convertir a las niñas en ángel del hogar (Burgos 1931: 23-24). Más adelante, plasma el abismo entre las partidarias de la tradición y quien se opone a ella de la siguiente manera. Primero, evoca negativamente a doña Rosario y a su acompañante, generando rechazo y repulsión, en el lector, la negatividad de su retrato físico, obvia en la adjetivación. Para ello, recurre a la red paradigmática de la vejez: "una señora larga, seca como un látigo, bigotuda y patilluda, con vello cerdoso hasta dentro de la nariz, y una rigidez que aumentaba su sordera". También acude a la isotopía del inmovilismo y del anquilosamiento, "otra señora gordita a la que parecía haberle comunicado su alelamiento, según lo lenta y helada que era para hablar y para moverse". Por último, alude a la molestia de quien se opone a ella "Isabel se sentía molesta en aquel medio":

Casi todas las demás estaban conformes con ese deseo, menos Rosa, que no concebía otra vida distinta de la suya. La más entusiasta era doña Rosario, una señora larga, seca como un látigo, bigotuda y patilluda, con vello cerdoso hasta dentro de la nariz, y una rigidez que aumentaba su sordera. Se mostraba en teoría tan gran enemiga de los hombres como lo era en realidad de las mujeres. Iba siempre acompañada de otra señora gordita a la que parecía haberle comunicado su alelamiento, según lo lenta y helada que era para hablar y para moverse. Siempre que le preguntaban algo tardaba en contestar lo bastante para dar tiempo a que resolviera doña Rosario. Isabel se sentía molesta en aquel medio. (Burgos 1931: 70)

En cambio, la referencia a Lina, criticada por los tradicionalistas, Rosita y Antonio, (Burgos 1931: 61), rebosa de rasgos positivos en palabras del sujeto de la enunciación:

Sólo Lina había sabido tomar ascendiente sobre ella. Se había hecho indispensable a su lado. Le ayudó a cambiar el decorado de la casa, con una elegancia sorprendente. Todos los muebles habían sido escogidos por Lina, sin descuidar ningún detalle. 
Gracias a su esfuerzo las habitaciones estaban llenas de comodidad, de rincones confidentes y agradables, sin nada vulgar ni chabacano. La dirigía también en sus trajes. Parecía tener el don de adivinar los caprichos de la moda antes de que se generalizasen. Isabel estaba satisfecha de los triunfos que obtenía por la influencia de su amiga. Se hacía elegante y bonita en un grado insospechado hasta para el mismo Julio. Era un triunfo de feminidad, de pleno desenvolvimiento de su belleza, cuyo poder dominaba a su marido. Ella lo conocía y sabía utilizarlo. (Burgos 1931: 59-60)

Éstas ensalzan los progresos asociados a la modernidad, la elegancia, la comodidad, la moda, la coquetería con hipérboles valorativas "sorprendente", "llenas", "en un grado insospechado", al tiempo que descartan los productos de la tradición evidenciando su chabacanería y vulgaridad consustancial "sin nada vulgar ni chabacano".

\title{
2. LA IDENTIFICACIÓN DEL LECTOR A LAS FIGURAS ANSIADAS COMO MODELO
}

\subsection{Morir sola (1910) de María del Pilar Sinués}

El lector percibe la realidad, a través de la focalización de Cecilia Bustamante, compartiendo su vida interior. Mediante la transcripción de esta actividad mental, se le incita a identificarse con ella, implicándole, personal y afectivamente, al hacerle partícipe de lo que está viviendo con dos modalidades discursivas, como apuntan las líneas siguientes:

\begin{abstract}
Al oír hablar del abandono de la noble casa de los Barrientos su corazón ya conmovido [...] se oprimió de pena; la terrible urdimbre de los amores de Alicia y del duque le horrorizaba, aquella inspiraba a su espíritu recto y honrado una antipatía profunda $[\ldots]$. Pero lo que despertaba tan locas ambiciones y tan ansiosas esperanzas de goces de aquellos corazones venales, sublevaban de asco y de horror el noble corazón de Cecilia. (Sinués 1910: 239-242).
\end{abstract}

La del estilo indirecto libre representa, primero, pensamientos y palabras supuestamente pronunciadas, insertando interferencias e hibridaciones de su discurso propio: "la terrible urdimbre" "le horrorizaba". La verbalización de su conciencia paroxística, manifestada en las emociones, se advierte luego, tamizada por el sujeto de la enunciación que la interpreta merced a la recurrencia de hipérboles de contenido semántico altamente 
negativo. Y como se supone, el lector va a otorgar un crédito básico a este análisis interpretativo "lo que despertaba tan locas ambiciones y tan ansiosas esperanzas de goces de aquellos corazones venales sublevaban de asco y de horror el noble corazón de Cecilia" que dimana del hablante privilegiado y voz autorizada del relato.

\subsection{La roca del amor (1924) de Dolores de Gortázar Serantes}

La imagen de Rosa que se ofrece al lector se suministra desde el enfoque elogioso, compadecido y benévolo de su padrino, Don Pablo, que relata su vida y la de Rosina mediante la perspectiva laudativa del inconsolable Edmundo quien no logra superar su pérdida. A veces, coinciden ambas evaluaciones positivas respecto a Rosina. En las siguientes líneas, se articulan, en torno a la asimilación metafórica a una flor y las sucesivas sinécdoques que ponderan, admirativamente, su bondad e inocencia, reduciendo su alma, a la de un ángel y su cuerpo al cáliz crístico "hallé una flor aún bella, pero tronchada. ¡Era vuestra Rosina! ¡Un alma de ángel en un cáliz de inocencia!” (Gortázar Serantes 1924: 194). Por tanto, el destinatario de ambas valoraciones se apropia de la representación positiva facilitada que le incita a identificarse con las dos jóvenes, sucesivamente, compartiendo los pensamientos de cada una y, percibiéndolas, gracias a esta dimensión psíquica como individualidades dotadas de psicología en las que se puede reconocer.

\subsection{Quiero vivir mi vida (1931) de Carmen de Burgos}

El sujeto de la enunciación va a programar textualmente el reajuste de las mentalidades que requiere el feminismo, atrapando al lector en sus redes para incitarle a adoptar en su propia vida real el posicionamiento crítico textualizado, creando, conformando y dirigiendo una opinión pública en torno a esta necesidad consensual. La incitación a adquirir conciencia de la situación lastimosa en que se encuentran las mujeres españolas y a salir predispuesto a acoger, con benevolencia, los cambios necesarios mediante la refiguración de la mímesis, requiere hacerle insoportable esa realidad ficcionalizada a través de su identificación a Isabel. Para ello, facilita el acceso directo a sus espacios emocionales (ansiedad, inquietud, tristeza, melancolía, angustia, turbación) con los disturbios físicos ocasionados, vinculándose sistemáticamente la expresión violenta de sentimientos y emociones con el malestar generado por el agobio de vivir su condición como a continuación: 
Sin saber cómo, no tardaba ella en sentirse de nuevo nerviosa, hostil para con su marido. Experimentaba una especie de deseo de vengar ofensas que no había recibido, como si fuese la representante de todo un sexo humillado por la fuerza y la arbitrariedad de otro sexo, cuando guardaba tantos elementos suyos que no se podía someter. (Burgos 1931: 39)

Aquí, la tercera persona del narrador interviene para transmitir la información, en pretérito imperfecto e indefinido, desde un ángulo de visión fundido con la protagonista cuyos pensamientos y emociones penetra "no tardaba ella en sentirse de nuevo nerviosa, hostil para con su marido". Luego, deja paso al estilo indirecto libre que nos pone en contacto más próximo con el discurso de Isabel cuyos pensamientos y palabras supuestamente pronunciadas representa: "Experimentaba una especie de deseo de vengar ofensas que no había recibido, como si fuese la representante de todo un sexo humillado por la fuerza y la arbitrariedad de otro sexo, cuando guardaba tantos elementos suyos que no se podía someter". Y, en las líneas siguientes, su conciencia paroxística manifestada en las emociones, se verbaliza, primero, tamizada por el sujeto de la enunciación que la comenta e interpreta, segundo, con el estilo directo que desligado de él añade la ilusión de interioridad en el personaje de ficción al tiempo que una emancipación discursiva similar a su afán de liberación:

En aquellos momentos sentía Isabel verdadero pánico de que una traición de la naturaleza la pusiera, contra su voluntad, en ese trance. Apoyó la frente en el cristal de la pecera para sentir en el cerebro frescor de agua. - Yo no debía haberme casado-se repitió por millésima vez. Sentía angustia de verse expuesta a una forzosa maternidad. En el fondo de su ser había una protesta contra el predominio femenino de su morfología. Vagamente formulaba en su interior una aspiración suprema: - iSi yo fuese hombre! (Burgos 1931: 33-34)

En resumen, las tres novelas analizadas dan cuenta de la actitud de sus respectivas autoras ante su entorno, facilitando en la réplica del mundo real, que no les satisface, hitos ideológicos, destinados a enmendarlo a modo de plataforma de difusión masiva de su ideario. 


\section{VERDADES CONSAGRADAS COMO PLATAFORMA DE DIFUSIÓN DEL IDEARIO DE CADA} AUTORA

\subsection{Morir sola (1910) de María del Pilar Sinués}

Las verdades consagradas diseminadas por el sujeto de la enunciación en la representación de los personajes femeninos cuadran, en nuestra opinión, con los elementos ideológicos que difundió la autora, en algunos capítulos de Un libro para las damas: estudios acerca de la educación de la mujer (1910): Enfermedad mortal ${ }^{18}$, La belleza y la gracia ${ }^{19}$, La verdadera cristiana ${ }^{20}$, La hermosura y elegancia ${ }^{21}$, La coqueta ${ }^{22}$, El lujo ${ }^{23}$. También afloran idénticos datos, en otros de La dama elegante: manual práctico y completísimo del buen tono y del buen orden doméstico (1880): La mujer en su casa y en la sociedad ${ }^{24}$, La buena ama de casa ${ }^{25}$, Goces y esplendores del hogar ${ }^{26}$, o los tres siguientes de Verdades dulces y amargas : páginas para la mujer (1898), Las niñas mimadas $^{27}$, Economía y prodigalidad ${ }^{28}$, La instrucción en la mujer ${ }^{29}$.

\subsection{La roca del amor (1924) de Dolores de Gortázar Serantes}

Dos ejemplares de El Cruzado español evidencian el posicionamiento ideológico de la autora. El del 22 de noviembre subraya su enaltecimiento de la figura de Agustina de Aragón: "No han muerto las descendientes de la Heroína de Zaragoza. Están aquí, en el seno de la Tradición, dispuestas a todos los sacrificios y todas las abnegaciones por su fe y por su España" (Velásquez 1929: 3). El del 30 de mayo mediante un comunicado da cabida a su incitación a combatir el feminismo rojo reorientando la acción de las mujeres católicas hacia los ideales jaimistas:

Hoy-que al feminismo en todos los sectores se le considera como principal imperante factor en la colaboración política, y los enemigos del Catolicismo

\footnotetext{
${ }^{18}$ p. 29

${ }^{19}$ p.69

${ }^{20}$ p. 75

21 p. 161

22 p. 205

${ }^{23}$ p. 305

${ }^{24}$ p. $105-206$

${ }^{25}$ p. 209-265

${ }^{26}$ p. 270-301

${ }^{27}$ p. 9

${ }^{28}$ p. 205

${ }^{29}$ p. 315-322
}

Raudem, Revista de Estudios de las Mujeres. Vol. 9, 2021. ISSN: 2340-9630 
conceden grandes privilegios a las mujeres rojas, que laboran con vehemencia y fruto dañino, pero abundante - es necesario que la política jaimista se percate de la importancia imprescindible del laboreo de la mujer en su acción, y que siendo, como es, buena y activa por sus Ideales purísimos, mucho puede laborar en el campo jaimista, sembrando el bien y tomando parte más directa en las cuestiones palpitantes jaimistas no quedando relegada simplemente a una labor benéfica, hermosa. (Gortázar Serantes 1930: 2)

Estos datos afloran en las críticas que se le hacen a Lucila y en palabras de Don Pablo:

- ¡Por Dios! no habléis de carencia de entusiasmos en una tierra donde hasta las mujeres supieron inmortalizar su nombre en la Historia, como lo hizo Agustina de Aragón, cuando, despertando a Zaragoza con el ruido del cañón potente, demostró a Europa, al mundo entero, lo que una mujer española puede. (Gortázar Serantes 1924: 39)

\subsection{Quiero vivir mi vida (1931) de Carmen de Burgos}

En las réplicas siguientes de la novela, se perciben las conclusiones de El divorcio en España, asimilado a un signo de progreso y conquista de la civilización que admite la mayoría de los países y conviene a la sociedad y la moral (Burgos 1904: 142):

— Pero, si te es tan odioso, ¿por qué no te separas de él?

— ¡Separarnos! —exclamó Joaquina como si reaccionara ante aquella idea-.

Tú no sabes el escándalo que causaría en la provincia y cómo perjudicaría a nuestro buen nombre, a nuestra familia.

— Podéis verificar la separación amistosamente. Si él no te ama, no se opondrá a... El orgullo de mujer casada de Joaquina la atajó.

— No lo creas...; mi marido me quiere ... estoy segura. (Burgos 1931: 111)

Aquí se plasma, con toda vigencia, la oposición candente entre partidarios de la tradición católica y sus adversarios, delatando el sujeto de la enunciación, su apego a la modernidad y a sus aportaciones, en la manera de escenificar el enfrentamiento entre ambas posturas. Efectivamente, destaca la actitud inmediata e irreflexiva de Joaquina basada en el qué dirán con varios recursos. El uso de signos de admiración y puntos suspensivos traduce turbación y temor, la repetición del posesivo de primera persona del plural reivindica un 
grupo colectivo que hay que proteger, su exasperación se manifiesta en la interrupción de su interlocutor.

Elementos ideológicos de La mujer moderna y sus derechos (Burgos 1927: 19-21) vienen salpicando el relato, recalcando la injusta desigualdad de género, quien la padece en estilo directo, con puntos suspensivos y signos de admiración, para hacer al lector partícipe del desajuste:

Tú eres hombre... tienes todos los privilegios... Yo, mujer, soy la responsable ante Dios de todo... de tus pecados y de los míos... ¡Es terrible, terrible ser mujer...! ¡Hay que sufrirlo todo...todo...! ¡Hasta la condenación eterna! (Burgos 1931: 219)

\section{Conclusiones}

La representación de la mujer, analizada en las tres novelas, responde a finalidades específicas enfocando la crítica desde perspectivas ideológicas distintas. La que se proporciona en Morir sola (1910) pretende incitar al lector a descartar, en su existencia real, las formas de vida de las que desbaratan, rotundamente, la postura conservadora de la Iglesia, asentada en la reclusión natural de la mujer, en el ámbito doméstico, atribuyéndole una sublime misión de madre y de ángel del hogar. Y, en consecuencia, le mueve a adoptar el comportamiento de las que se ajustan perfectamente a estos requisitos de obediencia y sometimiento entre las cuatro paredes de su casa. La que se escenifica en La roca del amor (1924) induce al lector a aplicar el verdadero mensaje de Cristo reprobando a las que lo desvirtúan con los desastrosos resultados de su interpretación errónea del mismo. La que se esboza en Quiero vivir mi vida (1931) programa el reajuste de las mentalidades que requiere el feminismo, creando, conformando y dirigiendo una opinión pública en torno a esta necesidad consensual, suscitando, por un lado, la repulsión del lector hacia las que se aferran a la tradición católica y sus recomendaciones seculares, por otro lado, su simpatía hacia las que pretenden combatirlas librándose de ellas en nombre de la modernidad.

\section{REFERENCIAS BIBLIOGRÁFICAS}

Adam, Jean-Michel. 1999. Linguistique textuelle. Des genres de discours aux textes. Paris: Nathan. 
Angenot, Marc. 1989. 1889: un état du discours social. Longueuil (Québec): Le Préambule.

Aristóteles. 1999. La Retórica. Introducción, traducción y notas por Quintín Racionero. Madrid: Gredos.

Benvéniste, Emile. 1966. "Les relations de temps dans le verbe français", Problèmes de linguistique générale, Paris: Gallimard. 237-250.

Burgos, Carmen de. 1931. Quiero vivir mi vida. Madrid: Biblioteca Nueva.

Burgos, Carmen de. 1927. La mujer moderna y sus derechos. Valencia: Ed. Sempere.

Burgos, Carmen de. 1904. El divorcio en España. Madrid: Viuda de Rodríguez Sierra.

Cros, Edmond. 2005. Le sujet culturel. Sociocritique et psychanalyse. Paris: L'Harmattan.

Genette, Gérard. 1980. Figuras III. Barcelona: Editorial Lumen.

Genette, Gérard. ([1987] 2001). Umbrales. Ciudad de México: Siglo Veintiuno Editores. Traducción de Susana Lage.

Gortázar Serantes, Dolores de. 1924. La roca del amor: novela. Madrid: Rubiños.

Gortázar Serantes, Dolores de. 1930 “Acción de las Margaritas madrileñas" en El Cruzado español. 30 de mayo: 2.

Iser, Wolfgang. 1994. Stéréotype et lecture. Liège: Mardaga.

Jouve, Vincent. 1993. La lecture. Paris: Hachette.

Kerbrat-Orecchioni, Catherine. 1999. L'énonciation: de la subjectivité dans le langage. Paris: A. Colin.

Marchese Angelo y Forradellas Joaquín. 1991. Diccionario de retórica, crítica y terminología literaria. Barcelona: Ariel (colección Letras e Ideas/Instrumenta).

Marin, Louis. 1994. De la représentation. Paris: Gallimard Le Seuil.

Nash, Mary. 1983. Mujer, familia y trabajo en España (1875-1936). Barcelona: Anthropos.

Ricoeur, Paul. 1983. Temps et récit 1. L'intrigue du récit historique. Paris: Seuil.

Ricoeur, Paul. 1984. Temps et récit 2. La configuration dans le récit de fiction. Paris: Seuil.

Ricoeur, Paul. 1985. Temps et récit. 3 Le temps raconté. Paris: Seuil.

Sinués Marco, María del Pilar. 1910. Morir sola. Madrid: Librería General de Victoriano Suárez (Viuda e Hijos de Tello).

Sinués Marco, María del Pilar. 1910. Un libro para las damas: estudios acerca de la educación de la mujer. Madrid: Librería General de Victoriano Suárez (Estab. Tip. de la Viuda e Hijos de Tello).

Sinués Marco, María del Pilar. 1898. Verdades dulces y amargas: páginas para la mujer. Madrid: Librería General de Victoriano Suárez (Estab. Tip. de la Viuda e Hijos de Tello) $2^{\mathrm{a}}$ ed.

Sinués Marco, María del Pilar. 1880. La dama elegante: manual práctico y completísimo del buen tono y del buen orden doméstico. Madrid: Librería de A. de San Martín.

Suleiman, Susan Rubin. 1983. Le roman à thèse ou l'autorité fictive. Paris: PUF.

Velásquez, Aurelio. 1929. "Un éxito magno”en El Cruzado español. 22 de noviembre 1929: 3. 